\title{
Pengaruh Penggunaan Ampas Kelapa (Cocos nucifera L.) dalam Konsentrat dengan Level Berbeda terhadap Produksi Susu Kambing Nubian
}

\author{
The Effect of Utilization of Coconut (Cocos nucifera L.) Pulp by Different Levels \\ on Nubian Goat Milk Production
}

\author{
T. Dwiyana, T. Akbarillah, dan Hidayat \\ Jurusan Peternakan, Fakultas Pertanian, Universitas Bengkulu \\ Jalan Raya W. R. Supratman, Kandang Limun, Bengkulu, 38371 A \\ Corresponding e-mail : tithadwiyana15@gmail.com
}

\begin{abstract}
Coconut pulp (Cocos nucifera L.) in Concentrates with Different Levels to the Production of Nubian Goat Milk, using the Latin Square Design (RBSL) 3 replications, 3 aids and 3 periods. Treatment P0 = forage + concentrate without coconut pulp, $\mathrm{P} 1=$ forage + concentrate with $3.55 \%$ coconut pulp, $\mathrm{P} 2=$ forage + concentrate with $6.85 \%$ coconut pulp. The treatment was not significant $(\mathrm{P}>0.05)$ on consumption of fresh forage, DM forage, $\mathrm{CP}$ forage, $\mathrm{CF}$ forage, drinking water and body weight gain, increasing very significantly $(\mathrm{P}<0.01)$ of consumption of concentrated $\mathrm{CP}$, total $\mathrm{CP}$, Total $\mathrm{DM}$, total and real $\mathrm{CF}(\mathrm{P}<0.05)$ on consumption of fresh concentrate, DM concentrate, CF concentrate and milk production Consumption of CP concentrates highest P0 is 153,63 g/ head / day and lowest P2 is 56,07 g / head / day. Consumption DM concentrate highest P0 is 828,43 g/ head / day, and lowest P2 is $382,3 \mathrm{~g} /$ head / day. Consumption of CF highest P0 is 142,47 g/ head / day and lowest P2 is 53,82 g / head / day. The results of the study can be concluded using coconut pulp in a reduced consumption concentrate (concentrate, dry matter, crude fiber and crude protein concentrate) Giving 3.55\% coconut pulp, still gives good results on the production of Nubian goat milk of $\mathrm{P} 0$ is $1415.24 \mathrm{ml} /$ head / day, P1 is $1325.24 \mathrm{ml} /$ head / day and $\mathrm{P} 2$ is $1127.86 \mathrm{ml} /$ head / day.
\end{abstract}

Keywords: Nubian goat, coconut pulp, consumption of nutrition DM, CP, CF, milk production.

\begin{abstract}
ABSTRAK
Penelitian ini bertujuan untuk mengevaluasi pengaruh penggunaan Ampas Kelapa (Cocos nucifera L.) dalam Konsentrat dengan Level Berbeda terhadap Produksi Susu Kambing Nubian, dengan menggunakan Rancangan Bujur Sangkar Latin (RBSL) 3 ulangan, 3 perlakuan, dan 3 periode. Perlakuan P0 $=$ hijauan + konsentrat tanpa ampas kelapa, $\mathrm{P} 1=$ hijauan + konsentrat dengan 3,55\% ampas kelapa, $\mathrm{P} 2=$ hijauan + konsentrat dengan $6,85 \%$ ampas kelapa. Perlakuan berpengaruh tidak nyata $(\mathrm{P}>0,05)$ terhadap konsumsi hijauan segar, BK hijauan, $\mathrm{PK}$ hijauan, SK hijauan, air minum dan pertambahan bobot badan. Perlakuan berpengaruh sangat nyata $(\mathrm{P}<0,01)$ terhadap konsumsi PK konsentrat, PK total, BK total, SK total yaitu menurunkan konsumsi; dan berpengaruh nyata $(\mathrm{P}<0,05)$ pada konsumsi konsentrat segar, BK konsentrat, SK konsentrat yaitu menurunkan konsumsi dan produksi susu. Konsumsi PK konsentrat tertinggi pada P0 yaitu 153,63 g/ekor/hari dan terendah pada P2 yaitu $56,07 \mathrm{~g} /$ ekor/hari. Konsumsi BK konsentrat tertinggi pada P0 yaitu 828,43 g/ekor/hari dan terendah pada P2 yaitu 382,3 g/ekor/hari. Konsumsi SK konsentrat tertinggi pada P0 yaitu, 142,47 g/ekor/hari dan terendah pada P2 yaitu 53,82 g/ekor/hari. Hasil penelitian dapat disimpulkan Penggunaan ampas kelapa dalam konsentrat menurunkan konsumsi (konsentrat, bahan kering, serat kasar dan protein kasar konsentrat). Pemberian 3,55\% ampas kelapa, masih memberikan hasil yang baik pada produksi susu kambing Nubian pada P0, P1, P2 secara berurutan yaitu $1415,24 \mathrm{ml} /$ ekor/hari, 1325,24 ml/ekor/hari dan $1127,86 \mathrm{ml} / \mathrm{ekor} /$ hari.
\end{abstract}

Kata kunci: Kambing Nubian, ampas kelapa, konsumsi nutrisi BK, PK, SK, produksi susu.

\section{PENDAHULUAN}

Kambing perah merupakan jenis kambing yang dapat memproduksi susu dengan jumlah melebihi kebutuhan anaknya (Atabany, 2002). Salah satu bangsa kambing perah yang adaptif di daerah tropis adalah kambing Anglo Nubian atau yang biasa disebut juga kambing Nubian. Kambing Nubian sangat potensial dikembangkan di Indonesia, terutama sebagai ternak penghasil susu yang dapat membantu memenuhi kebutuhan susu skala lokal maupun nasional.

Produksi merupakan kemampuan makhluk hidup untuk menghasilkan sesuatu yang 
bisa dimanfaatkan dan bernilai ekonomi, baik barang maupun jasa. Produksi ternak kambing Nubian sebagai kambing perah ialah produksi susunya. Pada puncak laktasi produksi susu mencapai 2-4 kg per hari dengan rata-rata $1-2 \mathrm{~kg}$ per hari.

Performa produksi susu kambing perah akan optimal apabila didukung oleh ketersediaan pakan dalam jumlah yang cukup dan kualitas yang baik. Harga bahan pakan yang cenderung meningkat dan tidak diimbangi dengan kenaikan harga produk peternakan dapat menurunkan kinerja industri peternakan. Menurut Soekartawi (2003), biaya produksi dibagi mnjadi 2 yaitu biaya tetap dan biaya variabel. Pakan termasuk kedalam biaya variabel yang memerlukan biaya cukup tinggi, maka perlu dicari komponen pakan alternatif yang murah dan tersedia.

Pemanfaatan limbah pertanian sebagai pakan ternak merupakan salah satu upaya mengatasi biaya pakan yang tinggi. Salah satu limbah pertanian yang belum dimanfaatkan secara optimal adalah ampas kelapa. Selama ini ampas kelapa sebagian besar dibuang begitu saja sehingga mencemari lingkungan dan nilai ekonomisnya rendah. Dengan memanfaatkan ampas kelapa untuk pakan ternak diharapkan dapat menggantikan sebagian penggunaan bahan pakan yang harganya tinggi sehingga dapat mengurangi biaya produksi sekaligus meningkatkan keuntungan. Ampas kelapa dapat digunakan sebagai pakanalternatif. .Menurut Soeharsono (2006), ampas kelapa mengandung BK 30\%, PK 6,44\% dan TDN 76,78\%.

Ampas kelapa yang merupakan bahan pakan nabati cukup berpotensi secara kuantitas karena jumlahnya yang cukup banyak, mudah diperoleh dan tersedia secara kontinyu. Pada tahun 2017 produksi kelapa di Indonesia mencapai 5.742.561 ton per tahun, sedangkan di Propinsi Bengkulu diproduksi sebanyak 9.179 ton kelapa pada tahun 2017 (Dirjen Perkebunan, 2017). Ampas Kelapa dapat diperoleh dari 30\% berat kelapa padat (Soeharsono, 2006)

Hijauan Makanan Ternak (HMT) adalah salah satu bahan makanan ternak yang sangat diperlukan dan besar manfaatnya bagi kehidupan dan kelangsungan populasi ternak. Hijauan berfungsi sebagai sumber nutrisi, yaitu protein, energi, vitamin dan mineral. Hijauan yang bernilai gizi tinggi cukup memegang peranan penting karena dapat meyumbangkan zat pakan yang baik bagi ternak (Herlinae, 2003). Secara umum kualitas hijauan didaerah tropis lebih rendah daripada di daerah subtropis karena kandungan $\mathrm{N}$ yang rendah dan kandungan serat kasar tinggi (Sumarsono et al. 2009). Selain itu, ketersediaan hijauan pakan tidak sepanjang tahun. Pada musim kemarau hijauan akan sulit untuk didapatkan, oleh karena itu perlu adanya tambahan konsentrat untuk mencukupi kebutuhan nutrisi ternak kambing perah.

Potensi ampas kelapa yang tinggi dapat dijadikan sebagai bahan pakan alternatif untuk ternak serta belum banyaknya penelitian mengenai hal tersebut, maka dilakukan penelitian pengaruh penggunaan ampas kelapa (Cocos nucifera L.) dalam konsentrat dengan level berbeda terhadap produksi susu kambing Nubian yang bertujuan untuk mengevaluasi pengaruh penggunaaan ampas kelapa (Cocos nucifera L.) dalam konsentrat dengan level berbeda terhadap produksi susu kambing Nubian. Penggunaan ampas kelapa (Cocos nucifera L.) dalam konsentrat dengan level berbeda diduga tidak menurunkan produksi susu kambing Nubian.

\section{MATERI DAN METODE}

Penelitian ini dilakukan pada tanggal 02 September - 13 Oktober 2019 di kandang kambing Jurusan Peternakan Fakultas Pertanian Universitas Bengkulu.

Bahan yang digunakan pada penelitian ini adalah 3 induk kambing perah, air hangat, anti septik, ampas tahu, dedak padi, mineral, jagung giling, ampas kelapa sangrai dan rumput.

Alat yang digunakan pada penelitian ini adalah ember, bak pakan, gelas ukur, kain lap, timbangan analitik, timbangan gantung, termometer, wet and dry (higrometer), sapu lidi, botol semprot, timbangan ternak dan botol susu.

\section{Persiapan Kandang}

Kandang yang digunakan pada penelitian ini termasuk dalam kandang tipe individual, yaitu dalam satu petak kandang hanya ditempati oleh satu ekor kambing. Kandang ini memiliki lantai dari bambu. Kandang dilengkapi dengan bak pakan, tempat minum kambing dan tempat konsentrat dengan ukuran tempat pakan panjang $114 \mathrm{~cm}$, tinggi $40 \mathrm{~cm}$, dan lebar $48 \mathrm{~cm}$,serta atap kandang yang digunakan adalah seng. Ukuran kandang (P x L x T) adalah 154 x 115 x $198 \mathrm{~cm}$. Jarak lantai kandang dengan tanah adalah $100 \mathrm{~cm}$. Lantai terbuat dari bilah bambu dengan jarak antar bilah bambu $3 \mathrm{~cm}$. Tempat pakan (rumput) dibuat menempel pada sisi depan kandang, terbuat dari papan. Tempat pakan (konsentrat) dan air minum menggunakan ember plastik. Sebelum penelitian 
dimulai, seluruh area kandang terlebih dahulu dibersihkan dan dilakukan penyemprotan desinfektan untuk mencegah pertumbuhan mikroorganisme penyebab penyakit, kemudian menempatkan alat pengukur suhu (termometer) dan kelembaban (higrometer) di dalam kandang.

\section{Persiapan Pakan}

Persiapan pakan meliputi : mencari ampas kelapa di pasar tradisional dengan cara memintanya kepada pedagang, melakukan penimbangan awal terhadap ampas kelapa, ampas kelapa disangrai sampai kering yaitu sampai warnanya coklat muda, setelah disangrai ampas kelapa ditimbang kembali untuk mengetahui berat kering, kemudian ampas kelapa disimpan didalam kantong plastik kedap udara. Ampas kelapa disangrai agar umur simpan lebih tahan lama.

Bahan konsentrat lainnya seperti ampas tahu, dedak, mineral, dan jagung giling didapatkan dengan cara dibeli. Setelah semua bahan pakan tersedia kemudian dicampur sampai homogen sesuai dengan Tabel 4. Pakan yang diberikan yaitu hijauan berupa rumput lapang dan konsentrat.

\section{Persiapan Ternak}

Pada penelitian ini menggunakan 3 ekorinduk kambing perah Nubian yang sedang laktasi pertama dengan umur laktasi 3 sampai 4 bulan. Kemudian menempatkan ternak penelitian tersebut pada kandang individu yang telah disiapkan. Pada bulan Maret sampai Agustus 2019 pakan ternak ditambahkan ampas kelapa, untuk mengetahui respon ternak terhadap ampas kelapa dan dilakukan adaptasi terhadap pakan penelitian pada pagi dan sore hari selama 2 minggu sebelum penelitian dilaksanakan.

Pemberian hijauan dan konsentrat dilakukan dua kali sehari yaitu pagi hari pukul 07.00 WIB dan sore hari pada pukul 16.00 WIB sesuai perlakuan. Pemberian rumput dalam bentuk segar. Air minum diberikan ad libitum (tersedia terus). Perlakuan yang diberikan adalah P0, P1, P2 yang dapat dilihat pada Tabel 1. Pengacakan perlakuan pada setiap ekor kambing dan pada Tabel 3. Komposisi dan kandungan nutrisi pakan yang diberikan. Sisa pakan ditimbang pada hari berikutnya, pengambilan sampel dilakukan di hari ke-5 sampai hari ke-14 pada setiap periode dan ternak ditimbang setiap awal dan akhir periode penelitian.

Tabel 1. Pengacakan perlakuan pada setiap ekor kambing

\begin{tabular}{lccc}
\hline \multirow{2}{*}{ Periode } & \multicolumn{3}{c}{ Kambing } \\
\cline { 2 - 4 } & 1 & 2 & 3 \\
\hline Periode I & P0 & P1 & P2 \\
Periode II & P2 & P0 & P1 \\
Periode III & P1 & P2 & P0 \\
\hline
\end{tabular}

Keterangan :

P0 $=36,76 \%$ ampas tahu $+3,55 \%$ dedak padi + $3,55 \%$ jagung giling $+0,74 \%$ mineral $+0 \%$ ampas kelapa + hijauan

P1 $=35,46 \%$ ampas tahu $+3,55 \%$ dedak padi + $3,55 \%$ jagung giling $+0,71 \%$ mineral + $3,55 \%$ ampas kelapa + hijauan

P2 $=34,25 \%$ ampas tahu $+3,42 \%$ dedak padi + $3,42 \%$ jagung giling $+0,68 \%$ mineral $+6,85$ $\%$ ampas kelapa + hijauan

Tabel 2. Kebutuhan nutrisi kambing

\begin{tabular}{cccccc}
\hline $\begin{array}{c}\text { Bobot badan } \\
(\mathrm{kg})\end{array}$ & $\begin{array}{c}\text { Produksi susu } \\
(\mathrm{kg})\end{array}$ & TDN (kg/hari) & $\begin{array}{c}\text { Protein } \\
(\mathrm{g} / \text { hari })\end{array}$ & MP (g/hari) & $\begin{array}{c}\text { DIP } \\
(\mathrm{g} / \text { hari })\end{array}$ \\
\hline 50 & 2,33 & 1,22 & 305 & 96 & 165 \\
\hline
\end{tabular}

Sumber : NRC, (2007)

Tabel 3. Komposisi dan kandungan nutrisi pakan (\%)

\begin{tabular}{lcccccc}
\hline \multirow{2}{*}{ Bahan Pakan } & \multicolumn{7}{c}{ Kandungan zat gizi (\%) } \\
\cline { 2 - 7 } & BK & PK & TDN & BK & PK & TDN \\
\hline Ampas tahu & 90,37 & 23,03 & 70,35 & 100,00 & 25,50 & 77,80 \\
Ampas kelapa* & 30,00 & 6,44 & 76,78 & 100,00 & 21,50 & 76,70 \\
Dedak padi & 86,00 & 11,90 & 70,00 & 100,00 & 13,80 & 81,40 \\
Jagung & 86,00 & 8,90 & 74,00 & 100,00 & 10,30 & 86,00 \\
Hijauan & 20,00 & 1,90 & 12,00 & 100,00 & 9,50 & 60,00 \\
\hline
\end{tabular}

Sumber: Hartadi et al. (1997)

Soeharsono, (2006)* 
Tabel 4. Komposisi dan kandungan nutrisi pakan pada setiap perlakuan

\begin{tabular}{lcccccc}
\hline \multirow{2}{*}{ Bahan Pakan } & PO & P1 & P2 & PO & P1 & P2 \\
\cline { 2 - 7 } & $\ldots \ldots \ldots \ldots$ & kg BK/hari $\ldots \ldots \ldots \ldots \ldots \ldots \ldots \ldots \ldots \ldots \ldots \ldots \ldots \ldots \ldots \ldots$ & $\ldots \ldots \ldots \ldots \ldots$ \\
Ampas tahu & 1,00 & 1,00 & 1,00 & 36,76 & 35,46 & 34,25 \\
Ampas kelapa & 0,00 & 0,10 & 0,20 & 0,00 & 3,55 & 6,85 \\
Dedak padi & 0,10 & 0,10 & 0,10 & 3,68 & 3,55 & 3,42 \\
Jagung & 0,10 & 0,10 & 0,10 & 3,68 & 3,55 & 3,42 \\
Mineral & 0,02 & 0,02 & 0,02 & 0,74 & 0,71 & 0,68 \\
\hline Hijauan & 1,50 & 1,50 & 1,50 & 55,15 & 53,19 & 51,37 \\
\hline Total & 2,72 & 2,82 & 2,92 & 100,00 & 100,00 & 100,00 \\
\hline Protein & 0,42 & 0,42 & 0,41 & - & - & - \\
\hline TDN & 1,85 & 2,02 & 2,20 & - & - & - \\
\hline
\end{tabular}

\section{Variabel yang diamati}

Variabel utama yang diamati yaitu konsumsi hijauan segar, konsentrat segar, konsumsi nutrisi BK, PK, SK dan total,pertambahan bobot badan dan produksi susu.

\section{Pertambahan bobot badan dan produksi susu}

Pemerahan susu dilakukan setiap hari selama penelitian pada pagi pukul 06.00 WIB dan sore hari pada pukul 16.00 WIB dan penimbanganbobot badan induk dilakukan pada awal dan hari terakhir disetiap periode.

\section{Konsumsi pakan segar}

- $\quad$ Konsumsi hijauan $=$ Hijauan yang diberikan - hijauan sisa

- Konsumsi kosentrat $=$ Konsentrat yang diberikan - konsentrat sisa

\section{Konsumsi nutrisi BK pakan}

- $\quad$ Konsumsi BK hijauan = Bk hijauan yang diberikan - BK hijauan sisa

- Konsumsi BK kosentrat $=$ BK konsentrat yang diberikan - Bk konsentrat sisa

- $\quad$ Konsumsi BK total $=$ Konsumsi BK hijauan + Konsumsi BK konsentrat

Konsumsi nutrisi PK Pakan

- $\quad$ Konsumsi PK hijauan = PK hijauan yang diberikan - PK hijauan sisa

- $\quad$ Konsumsi PK kosentrat $=$ PK konsentrat yang diberikan-PK konsentratsisa

- $\quad$ Konsumsi PK total $=$ Konsumsi PK hijauan + Konsumsi PK konsentrat

Konsumsi nutrisi SK Pakan

- Konsumsi SK hijauan = SK hijauan yang diberikan - SK hijauan sisa

- Konsumsi SK konsentrat= SK konsentrat diberikan - SK konsentrat sisa

- $\quad$ Konsumsi SK total = Konsumsi SK hijauan + Konsumsi SK konsentrat

\section{Variabel Pendukung}

Variabel pendukung meliputi konsumsi air minum, suhu dan kelembaban lingkungan.

\section{Konsumsi air minum}

Konsumsi air minum = air minum yang diberikan - air minum sisa

Suhu lingkungan

Suhu lingkungan diukur setiap hari pada pagi, siang dan sore hari dengan menggunakan termometer.

\section{Kelembaban lingkungan}

Kelembaban lingkungan diukur setiap hari pada pagi, siang dan sore hari dengan menggunakan higrometer.

\section{Rancangan Percobaan}

Penelitian ini menggunakan Rancangan Bujur Sangkar Latin (RBSL), dengan menggunakan 3 perlakuan, 3 ulangan dan 3 periode. Dalam satu periode yaitu selama 14 hari dan pengambilan data dilakukan selama penelitian.

\section{Analisis Data}

Data yang diperoleh dari lapangan dan analisis laboratorium diolah, kemudian dianalisis menggunakan sidik ragam (ANOVA) dan jika berpengaruhnyata $(\mathrm{P}<0,05)$ maka dilanjutkan dengan uji Least Significance Different (LSD) (Astuti, 1980).

\section{HASIL DAN PEMBAHASAN}

\section{Kandungan nutrisi bahan pakan}

Kandungan nutrisi bahan pakan yang digunakan pada penelitian ini berupa konsentrat P0, P1, P2 dan hijauan, yang dapat di lihat pada Tabel 5.

Pakan yang digunakan pada penelitian ini berupa konsentrat dan hijauan, pada pengamatan 
Tabel 5. Hasil analisis laboratorium nutrisi bahan pakan yang digunakan selama penelitian

\begin{tabular}{lccc}
\hline Pakan & BK & PK & SK \\
\hline Konsentrat yang diberikan P0 & & $\ldots \ldots \ldots \ldots \ldots \ldots \ldots \ldots \ldots \ldots \ldots \ldots \ldots \ldots \ldots \ldots \ldots$ & \\
Konsentrat sisa P0 & 89,82 & 16,63 & 15,44 \\
Konsentrat yang diberikan P1 & 89,77 & 14,88 & 11,68 \\
Konsentrat sisa P1 & 89,91 & 15,75 & 14,03 \\
Konsentrat yang diberikan P2 & 89,97 & 13,13 & 11,55 \\
Konsentrat sisa P2 & 89,75 & 13,13 & 10,34 \\
Hijauan yang diberikan PI & 89,93 & 13,13 & 22,37 \\
Hijauan yang diberikan PII & 91,79 & 7,00 & 23,50 \\
Hijauan yang diberikan PIII & 90,95 & 5,69 & 24,52 \\
Rataan hijauan yang diberikan & 90,82 & 7,44 & 22,46 \\
Hijauan sisa P0 & 91,19 & 6,71 & 23,12 \\
Hijauan sisa P1 & 91,86 & 5,83 & 21,44 \\
Hijauan sisa P2 & 91,39 & 6,42 & 6,13 \\
\hline
\end{tabular}

Keterangan : P0 (hijauan + konsentrat tanpa ampas kelapa), P1 (hijauan + konsentrat dengan 3,55\% ampas kelapa), dan P2 ((hijauan + konsentrat dengan 6,85\% ampas kelapa)

nutrisi (BK, PK, dan SK) hijauan yang diberikan yaitu rumput lapang.Konsentrat yang diberikan berupa campuran ampas tahu, ampas kelapa sangrai, dedak padi dan jagung giling serta ditambahkan mineral. Berdasarkan analisis laboratorium diketahui rataan kandungan nutrisi hijauan yang diberikan mengandung BK 91,19\%, PK 6,71\%, SK 23,46\%. Perbedaan kandungan BK konsentrat pada setiap perlakuan berkisar 0,07-0,16\%, pada kandungan PK berbeda berkisar 0,88-3,5\% dan pada kandungan SK konsentrat berbeda berkisar antara 1,44-4\%. Menurut Soeharsono (2006), kandungan gizi ampas kelapa cukup baik yaitu dari $30,36 \%$ bahan kering mengandung $98,45 \%$ bahan organik, $6,44 \%$ protein kasar, 5,24\% lemak kasar, 24,82\% serat kasar, $1,55 \%$ abu dan 76,72\% TDN. Hasil analisis laboratorium menunjukkan bahwa kandungan nutrisi PK dan SK pakan sisa lebih rendah dibandingkan kandungan nutrisi pakan yang diberikan.

\section{Konsumsi hijauan segar, konsentrat segar dan nutrisi BK, PK, SK dan total}

Konsumsi merupakan jumlah pakan yang dimakan oleh ternak yang akan digunakan untuk mencukupi kebutuhan hidup pokok (pertumbuhan) dan berproduksi. Pakan merupakan salah satu faktor penting dalam usaha peternakan. Jenis pakan dan nutrisi yang diberikan akan mempengaruhi produksi, kesehatan ternak dan pertumbuhan. Rataan konsumsi hijauan, konsentrat, nutrisi BK, PK, SK dan total selama penelitian tersaji pada Tabel 6 .

Hasil sidik ragam menunjukkan, bahwa perlakuan berpengaruh tidak nyata $(\mathrm{P}>0,05)$ terhadap konsumsi hijauan, BK hijauan, PK hijauan dan SK hijauan, karena hijauan yang diberikan sama yaitu rumput lapang. Dengan demikian, fisik, komposisi nutrient dan palatabilitas hijauan yang diberikan hampir sama. Hal ini menunjukkan bahwa penggunaan pakan ampas kelapa $3,55 \%$ dan $6,85 \%$ tidak mempengaruhi konsumsi hijauan segar, BK, PK dan SK hijauan.

Hasil sidik ragam menunjukkan, bahwa perlakuan berpengaruh nyata $(\mathrm{P}<0,05)$ terhadap konsumsi konsentrat, BK konsentrat, dan SK konsentrat dan berpengaruh sangat nyata $(P<0,01)$ terhadap konsumsi PK konsentrat, BK total, PK total dan SK total. Uji lanjut LSD pada konsumsi konsentrat, BK konsentrat, PK konsentrat, SK konsentrat, dan BK total, menunjukkan bahwa perlakuan dalam konsentrat P0 tidak berbeda nyata $(\mathrm{P}>0,05)$ dengan $\mathrm{P} 1$, sedangkan perlakuan $\mathrm{P} 0$ berbeda nyata $(\mathrm{P}<0,05)$ dengan $\mathrm{P} 2$. Hal ini karena konsentrat $\mathrm{P} 2$ mengandung ampas kelapa sangrai yang paling tinggi yaitu $6,85 \%$ yang belum disukai ternak, sehingga ternak melakukan seleksi pakan. Hal ini yang menyebabkan konsumsi konsentrat, BK, PK dan SK konsentrat pada P2 paling rendah (palatabilitas pakan rendah). Rataan konsumsi BK konsentrat berkisar antara 382,30-828,43 g/ekor/hari, rataan konsumsi PK konsnentrat berkisar antara 56,07153,63 g/ekor/hari dan rataan konsumsi SK konsentrat 53,82-142,97 g/ekor/hari. Rataan konsumsi BK, PK, SK konsentrat pada P0 lebih tinggi karena palatabilitas pakan pada P0 yang lebih tinggi. Menurut Simanihuruk dan Sirait (2010) faktor yang mempengaruhi konsumsi adalah kualitas gizi dan palatabilitas pakan.pakan 
Tabel 6. Rataan konsumsi hijauan, konsentrat, nutrisi BK, PK, SK dan total selama penelitian

\begin{tabular}{lcrrr}
\hline \multirow{2}{*}{ Konsumsi } & \multicolumn{3}{c}{ Perlakuan } & \multirow{2}{*}{$\mathrm{P}$} \\
\cline { 2 - 3 } & \multicolumn{1}{c}{$\mathrm{P} 0$} & $\mathrm{P} 1$ & $\mathrm{P} 2$ \\
Hijauan & $\ldots \ldots \ldots \ldots \ldots \ldots . \mathrm{g}$ /ekor/hari $\ldots \ldots \ldots \ldots \ldots \ldots \ldots$ \\
yang diberikan & 2521,47 & 2405,14 & 2505,55 & 0,43 \\
Bahan kering & 504,26 & 456,77 & 513,20 & 0,22 \\
Protein kasar & 39,53 & 37,13 & 37,87 & 0,65 \\
Serat kasar & 133,88 & 117,64 & 137,60 & 0,22 \\
Konsentrat & & & \\
yang diberikan & $5202,69^{\mathrm{a}}$ & $4762,69^{\mathrm{a}}$ & $3355,48^{\mathrm{b}}$ & 0,04 \\
Bahan kering & $828,43^{\mathrm{a}}$ & $740,49^{\mathrm{a}}$ & $382,30^{\mathrm{b}}$ & 0,02 \\
Protein kasar & $153,63^{\mathrm{a}}$ & $133,16^{\mathrm{a}}$ & $56,07^{\mathrm{b}}$ & 0,006 \\
Serat kasar & $142,97^{\mathrm{a}}$ & $118,39^{\mathrm{a}}$ & $53,82^{\mathrm{b}}$ & 0,02 \\
Total & & & \\
Bahan kering & $1314,14^{\mathrm{a}}$ & $1197,25^{\mathrm{a}}$ & $895,50^{\mathrm{b}}$ & 0,01 \\
Protein kasar & $192,19^{\mathrm{a}}$ & $170,27^{\mathrm{b}}$ & $93.94^{\mathrm{c}}$ & 0,003 \\
Serat kasar & $272,00^{\mathrm{a}}$ & $236,04^{\mathrm{b}}$ & $191,42^{\mathrm{c}}$ & 0,002 \\
\hline
\end{tabular}

Keterangan : P0 (hijauan + konsentrat tanpa ampas kelapa), P1 (hijauan + konsentrat dengan 3,55\% ampas kelapa), dan P2 ((hijauan + konsentrat dengan 6,85\% ampas kelapa)

yang memiliki palatabilitas rendah akan dikonsumsi secara terbatas untuk memenuhi kebutuhan hidup pokok ternak. Sedangkan, pakan yang mempunyai palatabilitas tinggi akan dikonsumsi lebih banyak maka tingkat palatabilitas dinyatakan dengan jumlah konsumsi total bahan kering per hari oleh ternak. Hasil penelitian ini sejalan dengan penelitian Devandra dan Leng (2011), yang menyatakan bahwa jumlah konsumsi ransum pada dasarnya tergantung pada palatabilitas dan karakteristik fisik.

Hasil uji lanjut menunjukkan, konsumsi PK total pada perlakuan P0 berbeda nyata $(\mathrm{P}<0,05)$ dengan $\mathrm{P} 1$, perlakuan $\mathrm{P} 0$ berbeda sangat nyata $(\mathrm{P}<0,01)$ lebih banyak dikonsumsi dibanding P2, dan perlakuan P1 berbeda sangat nyata $(\mathrm{P}<0,01)$ dengan $\mathrm{P} 2$, sedangkan konsumsi SK total pada perlakuan $\mathrm{P} 0$ berbeda nyata $(\mathrm{P}<0,05)$ dengan $\mathrm{P} 1$, perlakuan $\mathrm{P} 0$ berbeda sangat nyata $(\mathrm{P}<0,01)$ dengan $\mathrm{P} 2$, dan perlakuan $\mathrm{P} 1$ berbeda nyata $(P<0,05)$ dengan $\mathrm{P} 2$. Berdasarkan hasil tersebut, konsumsi nutrisi konsentrat juga dipengaruhi oleh palatabilitas pakan dan kemampuan ternak mengkonsumsi pakan itu sendiri. Menurut Astuti et al., (2009), konsumsi nutrisi dipengaruhi beberapa faktor seperti bobot badan, tingkat produksi susu dan kualitas bahan pakan. Konsumsi BK, PK dan SK konsentrat yang tinggi pada P0 dikarenakan banyaknya konsentrat yang dikonsumsi. Jumlah konsentrat yang dikonsumsi akan mempengaruhi besarnya nutrisi yang dikonsumsi. Palatabilitas, kapasitas alat pencernaan, serta kemampuan ternak untuk menyerap zat-zat makanan merupakan faktor yang ikut menentukan tingkat konsumsi. Oleh karena itu, konsentrat yang sama kandungan nutrisi makanannya belum tentu sama pengaruhnya dengan ternak. Menurut Supriyati et al. (2015), rataan konsumsi PK pada kambing Nubian sebesar $201 \mathrm{~g} / \mathrm{ekor} / \mathrm{hari}$.

\section{Konsumsi air minum, PBB dan produksi susu}

Konsumsi air minum dibutuhkan untuk membantu proses pencernaan, mengeluarkan bahan-bahan yang tidak berguna dari dalam tubuh seperti keringat, air kencing dan feses. Bobot badan ternak mengalami kenaikan atau penurunan yang dipengaruhi oleh faktor ternak itu sendiri dan jumlah pakan yang dikonsumsi. Menurut Mc Donald et al., (2002) pertumbuhan ternak ditandai dengan peningkatan berat badan dan adanya perkembangan ukuran-ukuran tubuh. Pertambahan bobot badan ternak ruminansia sangat dipengaruhi oleh kualitas dan kuantitas pakan, penilaian pertambahan bobot badan ternak sebanding dengan ransum yang dikonsumsi (Thalib et al., 2001). Konsumsi air minum, PBB dan produksi susu selama penelitian dapat dilihat pada Tabel 7. 
Tabel 7. Konsumsi air minum, PBB dan produksi susu selama penelitian

\begin{tabular}{lcccc}
\hline \multirow{2}{*}{ Variabel } & \multicolumn{3}{c}{ Perlakuan } & \multirow{2}{*}{$\mathrm{P}$} \\
\cline { 2 - 4 } & $\mathrm{P} 0$ & $\mathrm{P} 1$ & $\mathrm{P} 2$ & \\
\hline Konsumsi air minum (ml/ekor/hari) & 185,60 & 191,74 & 178,86 & 0,54 \\
Pertambahan bobot badan (g/ekor) & 2,03 & 0,47 & 0,00 & 0,26 \\
Produksi susu (ml/ekor/hari) & $1415,24^{\mathrm{a}}$ & $1325,24^{\mathrm{ab}}$ & $1127,86^{\mathrm{b}}$ & 0,05 \\
\hline
\end{tabular}

Keterangan : P0 (hijauan + konsentrat tanpa ampas kelapa), P1 (hijauan + konsentrat dengan 3,55\% ampas kelapa),dan P2 ((hijauan + konsentrat dengan 6,85\% ampas kelapa)

Hasil sidik ragam menunjukkan, bahwa perlakuan berpengaruh tidak nyata $(\mathrm{P}>0,05)$ terhadap konsumsi air minum. Rataan konsumsi air minum pada penelitian ini yaitu P0 sebanyak $185,595 \mathrm{ml} / \mathrm{ekor} /$ hari, P1 sebanyak 191,738 $\mathrm{ml} /$ ekor/hari dan pada P2 sebanyak 178,857 $\mathrm{ml} /$ ekor/hari. Menurut Devendra and Burn (1994), konsumsi air pada ternak sangat dipengaruhi oleh faktor lingkungan, keadaan makanan, kondisi fisiologis, temperatur air minum, temperatur lingkungan dan genetik ternak. Kebutuhan air pada kambing penelitian diduga dipenuhi dari konsumsi air dalam hijauan dan konsentrat yang diberikan. Volume air minum yang dibutuhkan kambing sangat bervariasi dipengaruhi oleh jenis, suhu lingkungan, jenis pakan yang diberikan dan kegiatan (Sarwano, 2008).

Hasil sidik ragam menunjukkan, bahwa perlakuan berpengaruh tidak nyata $(\mathrm{P}>0,05)$ terhadap pertambahan bobot badan kambing penelitian. Hal ini karena pada kambing penelitian memiliki umur dan fase yang sama yaitu kambing Nubian yang sedang laktasi pertama dengan umur laktasi 3 sampai 4 bulan dan konsumsi pakan selain berguna untuk pertambahan bobot badan juga berguna untuk memproduksi susu. Pertambahan bobot badan dipengaruhi oleh beberapa faktor antara lain total protein yang dikonsumsi setiap harinya, jenis ternak, umur, keadaan genetis lingkungan, kondisi setiap individu dan manajemen tata laksana (NRC, 2006).

Hasil sidik ragam menunjukkan, bahwa perlakuan berpengaruh nyata $(\mathrm{P}<0,05)$ terhadap produksi susu kambing selama penelitian. Hasil uji lanjut menunjukkan perlakuan P0 tidak berbeda nyata $(\mathrm{P}>0,05)$ dengan $\mathrm{P} 1$, perlakuan $\mathrm{P} 0$ berbeda nyata $(\mathrm{P}<0,05)$ dengan $\mathrm{P} 2$ dan perlakuan $\mathrm{P} 1$ tidak berbeda nyata $(\mathrm{P}>0,05)$ dengan $\mathrm{P} 2$. Rataan produksi susu pada P0, P1 dan P2 berturutturut yaitu 1415,24 $\mathrm{ml} /$ ekor/hari, 1325,24 $\mathrm{ml} /$ ekor/hari dan 1127,86 ml/ekor/hari. Produksi susu P2 paling rendah diantara perlakuan yang lain, hal ini disebabkan konsumsi konsentrat P2 paling rendah, dikarenakan konsentrat P2 mengandung ampas kelapa sangrai tinggi $(6,85 \%)$ sehingga palatabilitas konsentratnya menurun dan ternak kurang menyukai yang menyebabkan konsumsi nutrisi BK, PK dan SK konsentratnya juga rendah (Tabel. 6). Produksi susu pada P1 tidak berbeda nyata dengan $\mathrm{P} 2(\mathrm{P}>0,05)$ dengan perlakuan sama-sama menggunakan ampas kelapa sangrai, pada P2 mengandung ampas kelapa sangrai sebanyak 6,85\% dan pada P1 mengandung ampas kelapa sangrai sebanyak 3,55\%. Menurut Abidin dan Sodiq (2002), faktor yang mempangaruhi produksi susu yaitu faktor genetik bersifat individual yang diturunkan tetua kepada keturunannya dan faktor lingkungan adalah lingkungan fisik seperti suhu,kelembaban juga sistem pemeliharaan yaitu berupa tata laksana pemeliharaan ternak dan pemberian pakan yang saling berkaitan dan menunjang dalam usaha meningkatkan produksi susu ternak Selain itu, produksi susu dipengaruhi oleh tahun musim beranak, umur dan jumlah laktasi (Atabany, 2001).

\section{Suhu dan Kelembaban kandang}

Suhu dan kelembaban yang diamati pada saat penelitian tersaji pada tabel 8 .

Tabel 8. Rataan suhu dan kelembaban selama penelitian.

\begin{tabular}{lcc}
\hline Waktu & Suhu $\left({ }^{\circ} \mathrm{C}\right)$ & Kelembaban $(\%)$ \\
\hline Pagi & 24,21 & 90,17 \\
Siang & 29,91 & 70,91 \\
Sore & 28,43 & 74,81 \\
\hline
\end{tabular}

Keterangan : Pagi (07.00), Siang (12.00), Sore (16.00) WIB

Hasil pengukuran suhu kandang pada pagi, siang dan sore hari saat penelitian berturutturut yaitu $24,21^{\circ} \mathrm{C}, 29,90^{\circ} \mathrm{C}$ dan $28,43^{\circ} \mathrm{C}$ dengan rata-rata suhu $27,5^{\circ} \mathrm{C}$ dan kelembabannya berturut-turut yaitu 90,17\%, 70,91\% dan 74,81\% dengan rata-rata 78,63\%. Menurut Yani (2005), bahwa ternak telah menunjukkan penampilan produksi baik apabila ditempatkan pada suhu 
lingkungan $18,3{ }^{\circ} \mathrm{C}$ dengan kelembaban $55 \%$. Ternak akan melakukan penyesuaian secara fisiologis dan secara tingkah laku, apabila suhu lingkungan dan kelembaban melebihi normal. Sedangkan menurut Qisthon dan Madi (2019), suhu lingkungan berkisar antara $25-30^{\circ} \mathrm{C}$ masih dalam keadaan normal dan kelembaban sekitar $75 \%$. Suhu dan kelembaban selama penelitian masih dalam kondisi normal.

\section{KESIMPULAN}

Penggunaan ampas kelapa dalam konsentrat menurunkan konsumsi (konsentrat, bahan kering, serat kasar dan protein kasar konsentrat). Pemberian 3,55\% ampas kelapa, masih memberikan hasil yang baik pada produksi susu kambing Nubian. Pemberian konsentrat yang menggunakan ampas kelapa dapat diberikan $3,55 \%$ pada kambing Nubian yang sedang laktasi. Ampas kelapa diberikan dalam konsentrat dengan pengolahan yang lain agar dapat meningkatkan palatabilitas pakan dan dapat meningkatkan produksi susu. Ampas kelapa adalah bahan pakan yang kandungan nutrisinya baik dan tersedia melimpah di Bengkulu, sehingga bisa dijadikan sebagai konsentrat yang mudah di aplikasikan untuk pakan ternak kambing jika diolah dengan baik.

\section{UCAPAN TERIMAKASIH}

Penulis mengucapkan terimakasih kepada PT Indofood Sukses Makmur Tbk, yang telah mendanai penelitian ini melalui program Indofood Riset Nugraha periode 2019/2020, dengan nomor kontrak [No. SKE.015/CC/IX/2019]

\section{DAFTAR PUSTAKA}

Abidin, J., \& A. Sodiq. 2002. Penggemukan Domba. Agromedia Pustaka, Jakarta.

Atabany, A. 2002. Strategi Pemberian Pakan Induk Kambing Perah Sedang Laktasi dari Sudut Neraca Energi. Makalah Pengantar Sains. Program Pascasarjana IPB. Bogor.

Atabany, A. 2001. Studi Kasus Produktivitas Kambing Peranakan Etawa dan Kambing Saanen Pada Peternakan Kambing Perah Barokah dan PT Taurus Dairy Farm.Program Pascasarjanan Institut Pertanian Bogor. Bogor.
Astuti, A., A. Agus dan S. P. S. Budhi. 2009. Pengaruh penggunaan high quality Feed Supplement Terhadap Konsumsi dan Kecernaan NutrientSapi Perah Awal Laktasi. Buletin Peternakan 33(2): 81-87.

Devendra C. and R.A. Leng. 2011. Feed Resources for animal in asia : issues, strategies for use, insentification and integration for increased productivi-ty. Asia-Aust. J. Anim. Sci. 24(3)303-321.

Dian, R., T. Hidayat, dan I Hernaman. 2015. Pengaruh Penggantian Rumput Lapang Oleh Limbah Penyulingan Daun Kayu Putih (Melaleunca cajuputi powell) pada Ransum Sapi Potong terhadap Jumlah Bakteri dan Protozoa Cairan Rumen (in vitro) Fakultas Peternakan, Universitas Padjajaran.

Dirjen Perkebunan, 2017. Statistik Perkebu-nan Indonesia Tentang Buah Kelapa. Jakarta.

[DPKH] Direktorat Jendral Peternakan dan Kesehatan Hewan. 2017. Statistik Peternakan dan Kesehatan Hewan 2017. Jakarta (ID) : Direktorat Jendral Peternakan dan Kesehatan Hewan Kementan RI.

Freitas VJF, D. Rondina, DM. Nogueira, AA. Simplicio. 2004. Post-Partum Anoestrus In Anglo-Nubian And Saanen Goats Raised In Semi-Arid Of Northeastern Brazil. Livestock Production Science 90: 219-226.

Hartadi, H., S. Reksohadiprodjo and A. D. Tillman . 1997. Tabel KomposisiBahan Pakan Untuk Indonesia. Gadjah Mada University Press.Yogjakarta.

Herlinae. 2003. Evaluasi nilai nurisi dan potensi hijauan asli lahan gambut pedalaman di Kalimantan Tengah sebagai pakan ternak (Tesis). Sekolah Pascasarjana, Institut Pernaian Bogor. Bogor.

Kaleka, N dan N. K. Haryadi. 2013. Kambing Perah. Solo: Arcita.Lasley, J. F. 1978. Genetics of Livestok Improvement. Prentice Hall of India Private. New Delhi

McDonald, P., R.A. Edwards, J.F.D. Greenhalgh dan C.A Morgan. 2002. Animal Nutrition. 6thEd. Asford Colour Pr. Gosfort. 
National Research Council. 2006. Nutrient Requirement of Sheep. National Academy Press. Washington.

National Research Council. 2007. Nutrient Requitments of Small Ruminants. National Academy Press. Washington, D.C.

Putri, M. F. 2010. Tepung Ampas Kelapa Pada Umur Panen 11-12 Bulan Sebagai BahanPanganSumber Kesehatan. Jurnal Kompetensi Teknik 1: 97-105.

Qisthon, A dan M. Hartono.2019. Respon Fisiologis dan Ketahanan Panas Kambing Boerawa dan Peranakan Etawa pada Modifikasi Iklim Mikro Kandang melalui Pengkabutan. JIPT Vol. 7(1): 206-211.

Saleh, E. 2004. Dasar Pengelolaan Susu dan Hasil Ikutan Ternak. Fakultas Pertanian Universitas Sumatera Utara. Medan..

Simanihuruk, K., J. Sirait. 2010. Silase Kulit Buah Kopi Sebagai Pakan Dasar Pada Kambing Boerka Sedang Tumbuh. Seminar nasional teknologi peternakan dan Veteriner. Loka Penelitian Kambing Potong. Sumatera Utara.

Soeharsono. 2006. Teknologi Pengolahan Limbah Padat VCO (ampas kelapa) untuk Pakan Ternak Ruminansia. Yogyakarta. Unpublished.
Soekartawi. 2003. Teori Ekonomi Produksi Dengan Pokok Bahasan Analisis CobbDouglas. PT Raja Grafindo Persada. 238 hal.Jakarta.

Sumarsono, A. Thanesya, dan L.K. Nuswantara. 2009. Kecernaan dan Fermentabilitas Hijaun Orok-Orok Secara In Vitro Sebagai Bahan Pakan Yang Ditanam Secara Tumpangsari Dengan Jagung Manis. Semarang. Animal Agriculture Journal 3(2): 281-291, Juli 2014.

Supriyati and B. Haryanto. 2015. Molasses protected palm kernel cake as source of protein for young male ettawah grade goats. JITV 16(1): 17-24.

Thalib, A., B. Haryanti, H. Hamid, D. Suherman dan Muyani. 2001. Effect of Combination of Defaunator and Probiotic on Rumen Ecosystem and Sheep Performance. Jurnal Ilmu Ternak dan Veteriner 6(2):83-88.

Yani, A. 2005. Pengaruh Iklim Mikro terhadap Respons Fisiologis Sapi Peranakan Fries Holland dan Modifikasi Lingkungan untuk Meningkatkan Produktivitasnya Pengaruh Iklim Mikro terhadap Respons Fisiologis Sapi Peranakan Fries Holland dan Modifikasi Lingkungan untuk Meningkatkan Produktivitasnya. Bogor : Departemen Ilmu Produksi dan Teknologi Peternakan, Fakultas Peternakan Institut Pertanian Bogor. 